http://dx.doi.org/10.4314/jae.v18i2.11

\title{
Preventive Measures Adopted by Nigerian Farmers for the Environmental Hazards in Cocoa Plantations
}

Famuyiwa B. S*., **D. O. Torimiro, B. O. Obatolu, E. O. Uwagboe

* Cocoa Research Institute of Nigeria

** Obafemi Awolowo University, Ile-Ife, Nigeria

*famuyiwabusayo@gmail.com

\section{Abstract}

The study investigated the adoption of environmental hazards preventive measures among cocoa farmers in Nigeria. It specifically identified and evaluated the preventive measures adopted by the farmers against environmental hazards associated with cocoa farming. A multistage sampling procedure was used in selecting 600 respondents from five geo-political zones where cocoa is commercially grown in the country. Results revealed that cocoa farming was dominated by male farmers (94\%) with a mean age of $48.6 \pm 14.0$ years, while $81.5 \%$ were literate. Fifteen environmental hazards preventive measures were adopted by the farmers, of which the highest adopted preventive measures were hygiene practices on the farm (48.8\%) and use of disease resistant varieties (48\%). The farmers indicated that they (61.5\%) never allowed crops to be less vulnerable, 57.8\% never adhered to cocoa certification procedure and55.7\% never practiced integrated pest management techniques. On the whole, however, $28.8 \%$ fell into high adoption category. The study further showed that there was a significant and positive correlation between adoption of environmental hazards preventive measures and farmers' yield at ( $r=0.936$; $p<0.05)$. This implies an increase in the yield of cocoa production vis-à-vis the adoption of environmental hazards preventive measures among the Nigeria cocoa farmers.

Keywords: adoption, environmental hazards, preventive measures cocoa farmers

\section{Introduction}

Among other crops of economic importance, cocoa is the largest non- oil export crop in Nigeria produced by smallholder farmers. Over 200,000 households in the 14 cocoa producing states in Nigeria depend on the crop as a source of livelihood (National Cocoa Development Committee (NCDC), 2008). Though Nigeria contributed $11 \%$ of the World's 3.5 million tons cocoa supply in 2005 (Nzeka, 2005), its benefits and contributions to the country's economy and people's health cannot be overemphasized. In 2002, it contributed $2 \%$ to the national export earnings (NCDC, 2008). Also, Agboola and Ochigbo (2011) claimed that Cocoa and cocoa preparations contributed $\$ 533.4$ million to Nigeria non-oil export earning between January and June 2011, Agbota (2014) claimed that cocoa contributed $\$ 900 \mathrm{~m}$ to Nigeria's economy in 2012. Studies have shown that the 
consumption of cocoa products performs the following health benefits: reduces fatigue, prevents malaria, diabetes and hypertension, among others (International Cocoa Organization ICCO, 2008).

However, cocoa production is faced with lots of problems of which insect pests and diseases are of paramount importance (Asogwa and Dongo, 2009, CRIN, 2010 and Iremiren, 2011). In an attempt to solve the various problems associated with cocoa farming, cocoa farmers engage in indiscriminate use of chemicals such as pesticides, insecticides, fungicides, and fertilizer which have always led to environmental hazards (Famuyiwa et al, 2013). As important as food is for human survival, there is a multidirectional relationship between agriculture that produces food and health. Gillespie, Ruel and Braun (2008) reported that agriculture is fundamental to good health while good health plays an important role in agricultural production; in term of quality labour. Most major health problems facing the world in recent times such as, inter alia, under nutrition, malaria, obesity, AIDS, food borne diseases, diet - related chronic diseases and a range of occupational health hazards are associated to agriculture that produces what we consume. On the other hand some of these major health problems can be corrected by food. To solve this problem, ICCO recommended best practices for cocoa bean to meet the stipulated European Union (EU) Maximum Residue Level (MRL) of $0.1 \mathrm{mg}$ and to avoid rejection of Nigerian cocoa bean from the World Market (Mohit, 2008). In achieving the stipulated EU recommendations, environmental hazardous preventive measures were recommended (ICCO, 2008).

Prevention is a phenomenon, which according to advanced learner dictionary (2000) is described as stopping bad from occurrence. However, Block (2004) explaining in terms of medical sciences described prevention as an investment to be leveraged rather than a cost to be justified. The cost of prevention is usually lower than the cost of cure. Among models of prevention, Diffusion of innovation has been a long standing theory on the spread of new ideas among groups of people or community and also the core of agricultural extension. Rogers (1960) defined diffusion as a process by which an innovation is communicated through certain channels over time among the members of a social system. The diffusion leads to individual innovation decision process which results to adoption categories and individual behavioral change. Famuyiwa and Torimiro, (2011) asserted that the key antecedents of behavioral change include knowledge, belief and attitudinal change. Foregoing indicates that to achieve best practice hence meeting the Minimum Residue level (MRL) of $0.01 \mathrm{mg}$ and a resultant cocoa farming that leads to sustainable standard in the aspect of economy, social, and environmental sustainability; it is germane to study the cocoa farmers' adoption levels on preventive measures against hazardous practices. This will create a gap for cocoa farmers training needs and capacity building, which are consequential to assure consumers of cocoa and cocoa products safety of consumption. 


\section{Objective}

The specific objectives of the study were to:

(a) identify socio-economic characteristics of cocoa farming in the study area;

(b) determine the cocoa farmers' knowledge of environmental hazards preventive measures in the study area; and

(c) identify and evaluate the preventive measures adopted by farmers against environmental hazards associated with cocoa farming in the study area.

\section{Hypothesis}

$\mathrm{H}_{0}$ : There is no significant relationship between farmers' cocoa yield and adoption of environmental hazards preventive measures

\section{Methodology}

A multistage sampling procedure was used in selecting respondents for the study using CRIN Geographical Information System (GIS) generated land use/ land cover in cocoa farms in Nigeria. Stage one involved purposive selection of five from six geo-political zones where cocoa is commercially grown in Nigeria. Stage two involved purposive selection (based on their production levels; the highest producing state was selected) of one state from each of the five geo-political zones that support commercial production of cocoa, this gave a total number of five states (Ondo, Kogi, Abia, Cross Rivers and Taraba) from the fourteen states. At stage three, selection of two local government Areas (LGAs) which were purposively selected (on their levels of production; the highest and the lowest producing LGAs) from the list of LGAs based on their production level of cocoa to give 10 LGAs. Stage four was a random selection of one community from the lists of communities in each LGAs to give 10 communities. While stage five involved systematic selection of 60 smallholder cocoa farmers from the list of cocoa farmers in each community to give 600 smallholders as the respondents for the study. A structured interview schedule was used to elicit information from the respondents while data were analyzed using descriptive and inferential statistical tools.

\section{Development of scale to measure environmental hazards preventive measures}

From exhaustive review of literature, (Eteng, 2005; ICCO, 2008; Tettey, et al., 2009; Wright and Boorse, 2010; and Ogunjimi and Farinde 2012), 15 preventive measures were identified, listed and measured against three likert scale; Never practiced with a score of 0 , Seldom practiced score 1, while practiced scored 2. The mean and standard deviation were calculated and farmers grouped into categories of adopters using adoption quotient as calculated by Sengupta (1967) in Shashekala et al 2012, into high, medium, low and no adopters using grand mean plus/minus standard deviation. 


\section{Results and Discussion}

\section{Socio-economic characteristics}

Table 1 shows respondents' mean age of $48.57 \pm 14.08$ year's standard deviation, with majority (83.1\%) below 60 years. Earlier study by Asogwa and Dongo (2008) indicated age as one of the problems of cocoa production, but the study revealed that more young people are going into farming; this was corroborated by Oluyole and Sanusi (2009) that more young people were entering cocoa farming in Cross Rivers. It also indicated that cocoa farming was among male with majority (94\%) supporting the claims of Oladipupo (2010) that distribution in farm work is skewed towards the male gender as a result of gender inequalities. However, it was also indicated that farmers were well experienced with a mean age of $24 \pm 14.9$ years. About 32.4 per cent had between 11 and 20 years, 23.2 per cent between 21 and 30 years, 19.6 per cent between 10 and 20 years, 11.5 per cent between 31 and 40 years while 13.1 per cent had more than 41 years of farming experience. Data in Table 1 also shows the distribution of cocoa farmers according to their farm size in $\mathrm{Ha}$. The data revealed that majority $(74.7 \%)$ of the farmers had between 0.5 and $10 \mathrm{Ha}, 14.3$ percent between 11 and $20 \mathrm{Ha}, 6.2$ percent between 21 and $30 \mathrm{ha}$, 0.8 cultivated between 31 and $40 \mathrm{Ha}$, while 4.0 percent cultivated above $40 \mathrm{Ha}$. The mean farm size in the study area was $10.4 \mathrm{Ha}$ with standard deviation of 2.0 . Respondents' mean farm age was $32.3 \pm 2.2$ years standard deviation. Very few (18\%) had farm equal or less than 10 years of age. About $48.67 \%$ of the respondents' farms were under productive age of 30 years, while about half $(51.3 \%)$ of the respondents cultivated farms that were more than 30 years old. It was further discovered that farmers' extension contact was very low with majority $(87.30 \%)$ not having contact while only $12.70 \%$ had contact. 
Table 1: Respondents' socioeconomic characteristics

\begin{tabular}{|c|c|c|c|c|}
\hline $\mathrm{S} / \mathrm{N}$ & Variables & Percentage ( $n=600$ ) & Mean & Std \\
\hline \multirow[t]{5}{*}{1} & Age & & 48.57 & 14.08 \\
\hline & $20-40$ & 36.9 & & \\
\hline & $41-60$ & 46.2 & & \\
\hline & $61-80$ & 15.1 & & \\
\hline & $81-100$ & 2 & & \\
\hline \multirow[t]{3}{*}{2} & Sex & & & \\
\hline & Male & 94 & & \\
\hline & Female & 6 & & \\
\hline \multirow[t]{8}{*}{3} & Years of farm & & & \\
\hline & 10 - 12years & 19.6 & 24 & 14.9 \\
\hline & 11 - 20years & 32.4 & & \\
\hline & 21 - 30years & 23.2 & & \\
\hline & 31 - 40years & 11.5 & & \\
\hline & $41-50$ years & 8.1 & & \\
\hline & 51 - 60years & 4.2 & & \\
\hline & > 60years & 0.8 & & \\
\hline \multirow[t]{6}{*}{4} & Farm size & & & \\
\hline & $0.5-10$ ha & 74.7 & 10.4 & 2.0 \\
\hline & $11-20$ ha & 14.3 & & \\
\hline & $21-30$ ha & 6.2 & & \\
\hline & $31-40$ ha & 0.8 & & \\
\hline & $>40$ ha & 4 & & \\
\hline \multirow[t]{9}{*}{5} & Age of farm & & & \\
\hline & $<10$ & 18 & 32.3 & 2.2 \\
\hline & $11-20$ years & 18.2 & & \\
\hline & 21 - 30 years & 12.5 & & \\
\hline & $31-40$ years & 20.3 & & \\
\hline & $41-50$ years & 17.8 & & \\
\hline & $51-60$ years & 8.3 & & \\
\hline & $61-70$ years & 1.5 & & \\
\hline & $>70$ years & 3.3 & & \\
\hline \multirow[t]{3}{*}{6} & Farmers' Exte & & & \\
\hline & Yes & 12.70 & & \\
\hline & No & 87.30 & & \\
\hline
\end{tabular}

Source: Field survey, 2012

\section{Level of education}

Figure 1 revealed the distribution of respondents according to their educational level. Among the respondents; $18.5 \%$ of the cocoa farmers did not have formal education, 
$24.5 \%$ did not complete primary school, while $16.8 \%$ completed primary school. $11.2 \%$ did not complete secondary, $16.3 \%$ completed secondary while $7.2 \%$ did not complete secondary and $5.5 \%$ completed post secondary school. Education is significant in adoption as the process of adoption is a mental process that involves individual decision making process. Though, Deji and Enuenwemba (2005) described that low level of education is a typical characteristics feature of an average rural area in Nigeria. Consequently, this low level of education may have a negative effect on adoption of preventive measure.

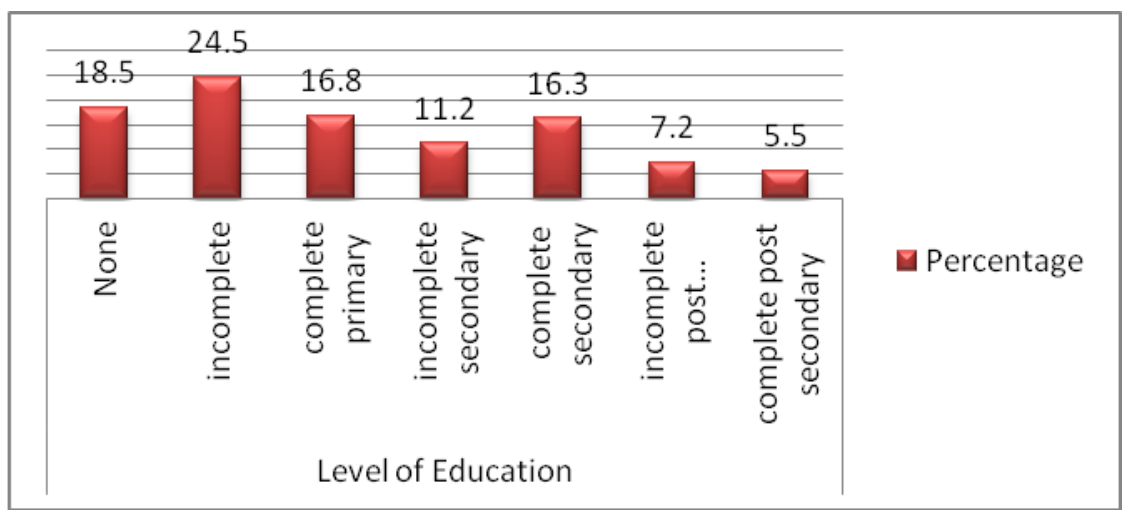

Figure 1: Showing Level of education of cocoa farmers in the study area.

Source: Field survey, 2012

\section{Membership of cocoa organization}

Figure 2 revealed that majority (68.7\%) of the respondents did not belong to any cocoa organization, while only $31.3 \%$ belonged to one cocoa organization or the other. It further revealed that $16 \%$ belonged to Cocoa Association of Nigeria, while $15.3 \%$ belonged to some other cooperative local groups. The result also implies that farmers may be more exposed to environmental hazards due to their sources of information. Membership in organization allows for peer influence among members hence having a significant influence on the innovation depending on the benefits members can find in it. Oduwole (2011) attributed that one major benefit of belonging to organization is the share of knowledge on innovation; this aids adoption as information about the innovation are shared among peers.

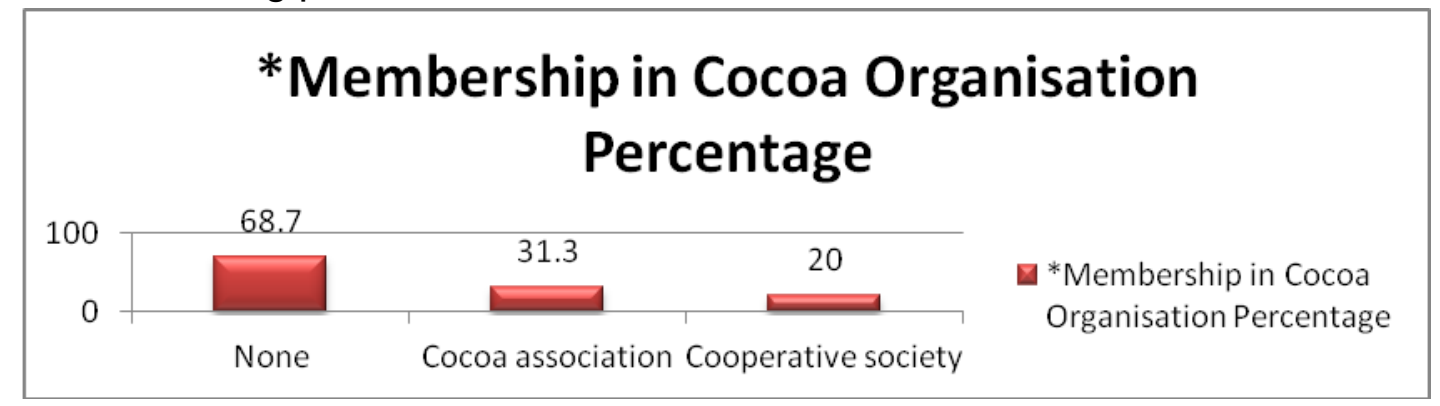


Figure 2: Showing farmers' membership in cocoa organization

Source: Field Survey, 2012

\section{Sources of information on prevention measures}

Table 2 revealed that input dealers $(70 \%)$, Friends and Neighbors $(60 \%)$ and Radio/Television (50\%) were the most frequent sources of information to cocoa farmers on environmental hazards preventive measures associated with cocoa farming. Other sources of information are other Association (45\%), Newspaper (35\%), Government agencies (30\%), Cocoa association (25\%) while Research Institute and Extension Agent/Agency were (20\%) each. Uwagboe (2010) corroborated this result that $70 \%$ of farmers in Edo State source their information from cocoa chemical dealers. The issue of information dissemination is very germane to adoption of innovation, more importantly the content and mode of the information transfer. This result implies that sources of information on issues of environmental hazards preventive measures to the respondents were not from approved sources. Hence there is likelihood for a negative influence on the adoption of preventive measures among the farmers. The result also implied that farmers may be more exposed to environmental hazards due to their sources of information.

Table 2: Distribution of respondents by sources of information on preventive measures against environmental hazards associated with cocoa farming

\begin{tabular}{lll}
\hline $\mathbf{S} / \mathbf{N}$ & *Sources of information & Percentage $(\mathbf{n}=\mathbf{6 0 0})$ \\
\hline 1 & Extension Agent/Agency & 20 \\
2 & Friends and Neighbors & 60 \\
3 & Cocoa farmers' association & 25 \\
4 & Other association & 45 \\
5 & Radio/Television & 50 \\
6 & Newspapers & 35 \\
7 & Research institutes & 20 \\
8 & Government & 30 \\
9 & Inputs dealers & 70 \\
\hline
\end{tabular}

Source: Field survey, 2012. $\quad{ }^{*}$ Multiple responses were recorded

\section{Production of farmers}

Table 3 shows the distribution of respondents with respect to their level of production. Majority (53\%) had low yield at equal less than $393 \mathrm{~kg} / \mathrm{ha}$, while $37.17 \%$ had high yield at greater than $503 \mathrm{ka} / \mathrm{ha}$, and $9.83 \%$ as medium level of yield. The mean production was $218.79 \mathrm{~kg} / \mathrm{ha}$ with standard deviation of 192.63 .

CRIN (2010) reported that the national average yield of cocoa/ha/year range from $393 \mathrm{~kg}$ - $503 \mathrm{~kg}$. While the release of new eight hybrid varieties; Tc1 - Tc8 produce between $1800 \mathrm{~kg}-2000 \mathrm{~kg}$. This report is used in categorizing the yield level of the farmers; using 
mean+/- standard deviation. The farmers that scored equal and above 503 is rated high, below $393 \mathrm{~kg}$ low and between $393 \mathrm{~kg}-503 \mathrm{~kg}$ rated medium.

This implies that majority were not producing at maximum level which could be as a result of farm age, insect pests and disease incidences and not adhering to recommended practices. This result is corroborated by Asogwa and Dongo (2008) that production of cocoa farm is low due to inappropriate use of chemical, farm age and age of trees.

Table 3: Distribution of respondents by level of production of cocoa

\begin{tabular}{lll}
\hline Production Level & Scores & Percentage $(\mathbf{n}=\mathbf{6 0 0})$ \\
\hline High Level & $>503 \mathrm{~kg}$ & 37.17 \\
Medium & $>393<503$ & 9.83 \\
Low Level & $393 \mathrm{~kg}<$ & 53.00 \\
\hline
\end{tabular}

Source: Field survey, 2012

Minimum $=11.67 \mathrm{~kg} / \mathrm{ha}$

Maximum $=993.06 \mathrm{~kg} / \mathrm{ha}$

Mean $=218.79 \mathrm{~kg} / \mathrm{ha}$

Standard deviation $=192.63$

\section{Knowledge and Adoption levels of environmental hazards preventive measures among cocoa farmers in five geo-political zones of Nigeria}

The respondents' knowledge on environmental hazards preventive measures was high as indicated on Table 5 . The farmers that had knowledge were $80 \%$ while without were $20 \%$. However, mean adoption score was 13.89 , standard deviation 8.13 , while maximum score was 30 and the minimum score 0.00 . Table 5 also shows categorization of the farmers into levels of adoption; using calculated adoption quotient. It shows the respondents' distribution by level of preventive measures adopted and rank order across five geo-political zones in Nigeria. On the whole, it revealed that $28.83 \%$ had high adoption, $60.67 \%$ medium, 8.5 low and only $5 \%$ did not adopt any of the measures. Consequently, based on the adoption levels, Southeast zone scored the highest adoption zone, while Southwest took the $5^{\text {th }}$ position. On the contrary, Southsouth had the highest knowledge with North central having the $5^{\text {th }}$ position.

Badilescu-Biga (2013) identified that knowledge gap is a key element in adoption of innovation; while adoption is defined as a five mental process all prospective customers go through from learning to acceptance or rejection of a new product. The result shows a great variability with respect of knowledge to adoption (practice). These results support the findings of Badcock-walter (2004) who claimed that knowledge does not equal to change and Uwagboe (2010) who in a study discovered that farmers who were trained on Integrated Pests Management (IPM) did not adhere to the practice. However, Asenso- 
Okyere and Davis (2009) explained that for proper articulation of knowledge and adoption, innovation knowledge created must be accumulated, shared, used and valued.

Table 4: Variability in knowledge and adoption levels of environmental hazards preventive measures among cocoa farmers in five geo-political zones of Nigeria

\begin{tabular}{|c|c|c|c|c|c|c|c|}
\hline \multirow[b]{2}{*}{$\begin{array}{l}\text { Adoption } \\
\text { Categories }\end{array}$} & \multirow[b]{2}{*}{ Scores } & \multicolumn{2}{|c|}{ Geo-political zones } & \multirow[b]{2}{*}{$\begin{array}{l}\text { South } \\
\text { south }\end{array}$} & \multirow[b]{2}{*}{$\begin{array}{l}\text { South } \\
\text { east }\end{array}$} & \multirow[b]{2}{*}{$\begin{array}{l}\text { North } \\
\text { east }\end{array}$} & \multirow[b]{2}{*}{$\begin{array}{l}\text { Total } \\
\text { Percent }\end{array}$} \\
\hline & & $\begin{array}{l}\text { South } \\
\text { West } \\
\text { Percent }\end{array}$ & $\begin{array}{l}\text { North } \\
\text { Central } \\
\text { Percent }\end{array}$ & & & & \\
\hline High & $\begin{array}{l}>22.02 \\
>5.76<22 .\end{array}$ & 15 & 13.33 & 0 & 33.33 & 39.17 & 25.83 \\
\hline Medium & 02 & 65 & 70.84 & 80.83 & 61.67 & 53.33 & 60.67 \\
\hline Low & $<5.76$ & 11.67 & 10 & 19.17 & 0 & 7.5 & 8.5 \\
\hline No adopter & 0 & 8.33 & 5.83 & 0 & 5 & 0 & 5 \\
\hline $\begin{array}{l}\text { Total } \\
\text { Adoption rank }\end{array}$ & 100 & 100 & 100 & 100 & 100 & 100 & 100 \\
\hline Order & & 5th & $3^{\text {rd }}$ & 4th & $1 \mathrm{st}$ & 2nd & \\
\hline
\end{tabular}

Knowledge

of

preventive

\begin{tabular}{llllllll} 
measures & Scores & Percent & Percent & Percent & Percent & Percent & Percent \\
\hline Yes & 1 & 85 & 72 & 92 & 73 & 76 & 80 \\
No & 0 & 15 & 28 & 8 & 27 & 23 & 20 \\
$\begin{array}{l}\text { Total } \\
\text { Knowledge }\end{array}$ & 100 & 100 & 100 & 100 & 100 & 100 & 100 \\
rank order & & $2^{\text {nd }}$ & $5^{\text {th }}$ & 1st & 4th & 3 rd & \\
\hline
\end{tabular}

Mean $=13.89$

Standard deviation $=8.13$

Minimum $=0$

Maximum $=30$

\section{Environmental hazards preventive measures in cocoa farming}

Table 5 shows the rank order of means by practice of preventive measures among respondents in the study area. Among the practices, only practice of sustainable farming practices (Good Agricultural Practices) mean score 5.44 and adherent to recommended agronomic practices a mean score value of 5.44 have high scores while others have low scores. Lawal et al. (2005), Uwagboe (2010) and Ogunjimi and Farinde (2012) differently established that cocoa farmers do not adhere to precautionary on the use of pesticides, hence expose themselves to environmental hazards. This implies that practice of preventive measures of environmental hazards associated with cocoa production were very low in the study area. 
Prevention is a process of militating against adverse effect. Block (2004) describing prevention in medicine says is an investment to be leveraged rather than a cost to be justified.

Table 5: Rank means scores of adoption of preventive measures associated with environmental hazards in cocoa production among the respondents

\begin{tabular}{llll}
\hline $\mathbf{S} / \mathbf{N}$ & Preventive measures & Mean scores & Rank order \\
\hline 1 & Adoption of sustainable farming practices & 5.44 & 1 \\
2 & Adherence to recommended agronomic practices & 5.44 & 1 \\
3 & Hygiene practices on the farm & 4.92 & 3 \\
4 & Level of education & 4.82 & 4 \\
5 & Adherence to cocoa certification programme & 4.79 & 5 \\
6 & Practicing of IPM techniques & 4.66 & 6 \\
7 & Specific cultural practices and farm rehabilitation & 4.1 & 7 \\
8 & Allowing crops to be less vulnerable & 3.98 & 8 \\
9 & Adherence to soil erosion prevention strategies & 3.71 & 9 \\
10 & Attendance of extension training & 3.32 & 10 \\
11 & Testing of soil before fertilizer application & 3.29 & 11 \\
12 & Attendance of farmers' group meeting & 3.06 & 12 \\
13 & Use of diseases resistant varieties & 2.27 & 13 \\
14 & Practicing of organic farming & 2.16 & 14 \\
15 & Regular medical checkups & 2.04 & 15 \\
\hline
\end{tabular}

Source: Field survey, 2012

\section{Correlation analysis}

There is no significant relationship between farmers' cocoa production and adoption of preventive measures of environmental hazards associated with cocoa yield. Table 6 shows that there is positive significant relationship between farmers' cocoa yield and the adoption of environmental hazards preventive measures. At $r$ - value $(0.936, p<0.05)$, coefficient of determination 0.876 and percentage of contribution $88 \%$, the null hypothesis is rejected. It indicated high percentage of contribution, which implies that as practice of preventive measures increase, production increases. Adoption of new and improved ways of avoiding hazards may make farmers less vulnerable and hence increase production.

Table 6: Correlation analysis showing relationship between cocoa farmers' yield and adoption of environmental preventive measures

\begin{tabular}{llll}
\hline & $\begin{array}{l}\text { Pearson } \\
\text { Coefficient }\end{array}$ & correlation & $\begin{array}{l}\text { Coefficient of } \\
\text { Determination } \\
(r)\end{array}$ \\
Variables & $\left(r^{2}\right)$ & $\begin{array}{l}\text { of } \\
\text { determinatio } \\
n\end{array}$ \\
\hline Adoption & $0.936^{*}$ & 0.88 & $88 \%$ \\
\hline
\end{tabular}

Source: Field survey, 2012. $\mathrm{P}<0.05$ 


\section{Conclusion and recommendation}

The following implications were drawn from the study

1. Farmers' cocoa yield was low compared to recommendation from CRIN that has research mandate to improve and increase cocoa yield at a sustainable level.

2. There is need to train cocoa farmers on prevention measures against environmental hazards for improve in yield, quality of cocoa beans and safety of farmers.

3. There was poor Extension/farmers contact; there is need for concerted effort from all stakeholders to come together in an innovation platform that allows information to flow.

4. There was high variability between knowledge and adoption; high knowledge did not translate to adoption

5. Adoption of preventive measures had positive and significant relationship to cocoa yield in the study area

Intensive innovation knowledge transfer needs to be effectively carried out to increase adoption of preventive measures hence, improve certification process among farmers.

\section{References}

Agboola, T. and Ochigbo, F. (2011) Nigeria earns N240b from non-oil exception in 6 months. The Nation News paper 01/12/2011

Agbota, S. (2013) Cocoa contributes $\$ 900 \mathrm{~m}$ to Nigeria's economy in $2012-\mathrm{BMI}$. The SUN July 15, 2013 assessed March 29, 2014, 8:12 PM WAT www.sunnewsonline.com

Asenso-Okyere, K. and Davis K. (2009) Knowledge and Innovation for agricultural development. International Food Policy Research Institute (IFPRI). www.ifpri.org/pubs/bp/bp0011.asp

Asogwa, E. U. and Dongo, L. N. (2009) Problems associated with pesticide usage and application in Nigeria cocoa production: A review African Journal of Agriculture Research Vol. 4 (8), pp. 675-683, August, 2009 Available online at http://www.academicjournals.org/AJAR.

Badcock-walters, P. Kelly, M. and Gorgenes, M. (2004) Does knowledge equal change? HIV/AIDS Education and Behaviour change 2004. Pp3

Badilescu-Buga E. (2013) knowledge behavior and social adopton of innovation. ScienceDirect information processing \& management vol. 49(4) 902-911. www.sciencedirect.com/science/article/piis0306457313000150

Block, D. J. (2004) The importance of preventive medicine. http://www.mainstreetuse.com/cfusc/RxPadofDaleBlock.htm

BusinessDictionary.com(2014) Product adoption process. 
$\underline{\text { www.businessdictionary.com/definition/product-adoption-process.html }}$

CRIN (2010)Scientific survey report of the cocoa production hectarage in Nigeria.

Unpublished report submitted to the National Cocoa development committee. December, 2008

David, M. and Nzeka, U. M. (2011) Nigeria cocoa production increases. Global agricultural information network (GAIN) report number N111018

Eteng, A. (2005) Rural development in Nigeria: Problems and remedies. Sophia: African journal of philosophy, vol 8, no 1 (2005)

Famuyiwa. B. S. and Torimiro. D. O. (2011) Perception of HIV/AIDS Prevention Strategies among Youth in the farming communities of Osun State of Nigeria. Journal of Agriculture and Rural Development. Swaziland. 2011. Vol. 6 pp 45-58

Famuyiwa, B.S., Torimiro, D.O, and Adesoji, S.A (2013) Determination of Cocoa Farmers' Knowledge on Environmental Hazards Associated with Cocoa Farming Operations in Nigeria. International Journal of Knowledge, Innovation and Entrepreneurship, Volume 1. Issues 1-2. 2013.

Gillespie S, Ruel, M. and Braun, J. (2008) Building bridges between agriculture and health. Prepared for the Global ministerial forum on research for health, Bamako, 17 - 19 Nov., 2008

ICCO, (2008) Manual of best known practices in cocoa production. Version 1. Consultative Board on the world cocoa economy sixteenth meeting Berlin, Monday, 26 May 2008 at $10.00 a m$ CB/16/2

Iremiren, (2011) Soil fertility and ageing cocoa farms in Nigeria. A paper presented in World cocoa foundation. Http://www.worldcocoafoundation.org/who-weare/partnership-meetings/documents/IremirenPresentationPDF.pdf

Lawal B. O., D. O. Torimiro, A. D. Banjo and A. O. Joda (2005) Operational Habits and Health Hazards Associated with Pesticide Usage by Cocoa Farmers in Nigeria: Lessons for Extension Work. J. Hum. Ecol., 17(3): Kamla-Raj 191-195 (2005)

Mohit, J. (2008) Nigerian farmers want government to buy off banned pesticides Submitted on Wed, 07/23/2008 - 14:35.http://www.topnews.in/

NCDC (2008) A handbook of the $4^{\text {th }}$ National Cocoa day held in Akure, Ondo State, Nigeria. Published by NCDC

Oduwole, O. (2011) Adoption of modern agronomic practices by cocoa farmers in Nigeria. A multivirate tobit analysis. Lambert Academic Publishing $\mathrm{GmbH}$ \& co. KG. Deutschland 
Ogunjimi, S.I., and Farinde A.J. (2012) Farmers' Knowledge Level of Precautionary Measures in Agro-Chemicals Usage on Cocoa Production in Osun and Edo States, Nigeria. International Journal of Agriculture and Forestry. 2012; 2(4): 186-194

Oladipupo, F. O., Kareem, O. W., Adereti, F. O., and Abubakar H. N(2010) Gender discrimination among the rural household in Edu Local Government Area of Kwara State, Nigeria. Journal of Agriculture and Rural Development. Vol. 62010 http://giard.net

Oluyole, K.A. and Sanusi, R.A. (2009). Socio-economic variables and cocoa production in Cross River State, Nigeria. J. Hum. Ecol. 25(1),5-8.

Uwagboe, E. O, (2010) Effect of integrated Pest Management (IPM) utilisation on cocoa farmers' yield in selected states of Nigeria. Unpublished M.phil thesis. University of Ibadan, Faculty of Agriculture, 2011.

Roger, E. M. (1960) Social change in rural society. A text book in rural sociology Appleton Century-Crofts, Inc. New York 1960 pp. 401-422

Shashekala, S.G., Govinda, G,V., Ravikumar, P. (2012) Adoption of soil and water conservation practices by groundnut farmers. International Journal of Advanced Biological Research I.J.A.B.R., VOL.2(1)2012:166-167 www.scienceandnature.org

Tettey, S., Ogoe, M., and David S.(2009) Preventing and reducing injuries and ill health in cocoa production: A guide for participating farmer training manual, no 4. Sustainable tree crops program. International Institute of Tropical agriculture IITA.www.iita.org/c/document library/get file?p | id=98898\&folderld=339194\&na $\underline{\mathrm{me}=\mathrm{DLFE}-1656 . \mathrm{pdf}}$

Wright, R. T. and Boorse, D. F. (2011) Environmental Science: Toward a sustainable future Plus mastering environmental science with Access card package, 11/E Four categories of human environmental hazards. wps.prenhall.com/esm_wright_envisci11_oa 